О. А. Остроушко канд. філол. наук, доцент

\title{
КОМУНІКАТИВНО-СЕМАНТИЧНІ ОСОБЛИВОСТІ ОДНОФРАЗОВИХ ЗАМОВЛЯНЬ-РОЗПОВІДЕЙ
}

У статті розглянуто семантичні й структурні особливості украӥнських однофразових замовлянь-розповідей. Ці особливості зумовлені своєрідним комунікативним призначенням досліджуваних текстів, їх магічною функиією. Замовляння-розповіді яскраво відбивають ряд психологічних особливостей мовців.

Замовляння посідають особливе місце серед фольклорних текстів. Поперше, вони одні з найдавніших, по-друге, мають яскраво виражене практичне призначення, по-третє - і це найбільшою мірою виявляє їх своєрідність - відображають цілий ряд рис магічного світобачення. Замовляння 
створені в надрах магічного світогляду, функціонують у його межах, поза якими втрачають усякий смисл. Сучасне наукове вивчення замовлянь одним із своїх аспектів і має висвітлення світоглядного підгрунтя цих текстів, їхнього глибинного прихованого змісту.

Значну частину українського заговірного фонду складають однофразові тексти - утворення, що складаються з одного висловлення, співвідносного з реченням (у ряді випадків - 3 комунікатом, що не $є$ реченням). Однофразові тексти замовлянь, зважаючи на характер модальності та комунікативно-функціональне призначення, поділяємо на такі комунікативносемантичні типи: замовляння-спонукання, замовляння-бажання, замовляння-розповіді. Структурно-семантичним різновидом замовлянь-бажань i спонукань $є$ чисельна група паралелістичних замовлянь.

До замовлянь-розповідей ( $\approx 30 \%$ від усієї кількості однофразових текстів) належать однофразові тексти, у яких мовець повідомляє про свої дії, дії магічних істот, певну ситуацію тощо. Основним граматичним показником цих замовлянь $\epsilon$ форма дійсного способу дієслів-присудків. Протиставлення трьох синтаксичних часів набуває своєрідного семантичного наповнення. Підкреслимо значну перевагу значень теперішнього й минулого часу в порівнянні з часовою віднесеністю висловлень до майбутнього часу (співвідношення приблизно 5:1). I справа тут не тільки в тому, що мовець інформує про дії, які відбуваються в момент мовлення чи відбувалися до нього. Такої часової віднесеності набувають дії, що є бажаними. I причина цього, на наш погляд, - в одній із особливостей міфологічного сприйняття часу: «Міфологічне мислення, - за словами М. Бахтіна, - локалізує в минулому такі категорії, як мета, ідеал, справедливість, досконалість, гармонійний стан людини й суспільства» $[1,183]$. Іншими словами, те, що насправді може бути чи має бути здійснене, що є бажаним у майбутньому, постає як таке, що вже відбулося, що сталося в минулому, або як таке, що існує зараз, у теперішньому. Причина цього - особливе ставлення до майбутнього: «Майбутне неоднорідне з теперішнім і минулим... воно позбавлене змістової конкретності, воно пусте й розріджене... Щоб наділити реальністю той чи інший ідеал, його мислять як такий, що вже був колись у золотому віці в «природному стані», чи мислять його існуючим у теперішньому десь за тридев'ять земель, за океанами, якщо не на землі, то під землею, якщо не під землею, то на небі» [1, 183-184]. Саме в такому «опредмечуванні» бажаного майбутнього, у наділенні його рисами реальності полягає магічна функція замовлянь-розповідей. Тому ми не погоджуємося 3 Ф. Зелінським, який вважав подібні замовляння похідними від паралелістичних, коли від формули порівняння залишається лише «зображення символу» - явища, 3 яким зіставляється бажане $[2,40]$. Світоглядні засади паралелістичних замовлянь і замовлянь-розповідей уявляються нам різними: принцип магічної аналогії та своєрідність сприйняття часу. 
За особливостями семантики виділясмо такі групи замовлянь-розповідей: повідомлення про дії мовця й повідомлення про дії магічних істот.

До замовлянь-повідомлень про дії мовця відносимо, у першу чергу, перформативні висловлення: «... Замовляю кров буйную, трав'яную $і$ водяную!» [У3, 59], «Я тебе одмовляю $і$ я тебе одвертаю $і$ я тебе замовляю: щоб ти тут не стояла і стачини не збавляла» [Українці, 280], "Я тебе змовляю, я тебе заговоряю, з кіс, з-під кіс, з очей, з-під очей, з губей, з-під губей...» [CМ, 26-27], «Ляк-перелячище, переполох-переполошище! Виговоряю з жовтої кості, з червоної крові, мущинські, жіночі, дівочі, парубочі, полночні, світові...» [CM, 22]. Функціонування перформативних висловлень у ролі однофразових текстів українських замовлянь обмежується наведеними прикладами. Подібні структури активно функціонують у складі кількафразових лікувальних замовлянь, у тому числі й текстові структури, що у своєму складі містять кличний комунікат і перформативне висловлення на зразок «Уроки вітряні, уроки земляні, уроки подумані й погадані $і$ стрічені! Викликаю, визиваю із його очей, із його плечей, із його жовтих костей, із його щирого серия, із раба Божого Якима» [УЧ, 52]. У ролі предикатів у перформативних висловленнях виступають такі дієслова (розташовані в порядку зниження частотності): «викликати», «визивати», «вишіптувати», «шептати», «замовляти», «одмовляти», «одшіптувати», «одговоряти», «вимовляти», «вибавляти» (лише в записах XX ст.), «заклинати», «проклинати», «виклинати» (останні чотири - одиничні випадки). Зафіксовано лише три приклади використання подібних перформативних конструкцій у замовляннях не лікувального призначення, хоча вони досить дотичні до цієї групи заговірних текстів - це замовляння «од гадюки» (від зміїних укусів): «Беру ласкою, замовляю Христом Богом з хлібом і святою паскою» [УЧ, 45], «Заклинаю вас, гадюки, іменем Господа намого Ісуса Христа і святого великомученика і побідоносия Георгія $і$ всіми небесними силами. Заклинаю три цариці: Куфію, Невію і Полію, щоб не вредили (старизю чи младению по імені) волосом (колір волосся)» [Українці, 120], «На морі, на лукомор'ї стоїть купа, а на тій купі лежить гадюка: я тую гадюку посічу, порубаю $і$ щиреє серие Івана замовляю» [УЗ, 157]. Типовим $\epsilon$ ускладнення перформативних висловлень рядами однорідних членів речення на позначення частин тіла, звідки виганяється хвороба. Місце перформативних висловлень у кількафразовому тексті не фіксоване.

Зауважимо, що дієслова на позначення словесного процесу замовляння функціонують також:

- у висловленнях із заміщеним суб'єктом дії на зразок «I не я ж вас (уроки - О. О.) визиваю, $і$ не я викликаю, - сам Господь визивав і викликав» [УЧ, 54], «Не я вишіптую (соняшниці - О. О.) - Мати Божа вишіптує» [УЧ, 81];

- у функції обставин мети дії: «Я буду од більма шептати» [Українці, 278], «nіду до скотини шептати» [Українці, 279], «-Куди йдеш? - До 
рожденого, молитвеного (ім'я) переляк вимовляти, визивати, переляк викликати, навій вимовляти, навій викликати, пристріт вимовляти, пристріт визивати» [CM, 23];

- у функції присудків у формі майбутнього часу і як частина складеного дієслівного присудка, ужитого у формі минулого часу, наприклад: «стала я вишіптувать, i визивать, і викликать (уроки - О. О.)» [УЧ, 53], «я буду од більма шептати» [Українці, 278];

- у складних синтаксичних конструкціях із зіставними часовими відношеннями на зразок «Ляку поки я не знала - не шептала, стала знать стала шептать» [BM, 36], «Поки я тебе не знала, то я тебе не визивала, я тебе не викликала, а тепер я тебе визиваю і викликаю» [УЧ, 84];

- у розповідних висловленнях із суб'єктом - магічною істотою: (син Герасим) «крикливиі викликав» [УЧ, 67], (красна дівиця) (Сус Христос) «кров замовляє» [УЧ, 35], (святая Варвара) «пристріт замовляла» [СМ, 27].

Семантичною групою замовлянь-повідомлень про дії мовця $\epsilon$ коментарі реально здійснюваних у процесі замовляння дій: «Сію кріп, щоб Бог родив» [Украӥниі, 244], "Оие я тебе підперезала, щэоб ти знала нащо!» [Українці, 235], «Андрію, Андрію, конопельки сію, спідницею волочу, заміж вийти хочу» [Воропай, 25-26]; повідомлення про уявні магічні дії мовця: «Журавлі, журавлі, я вам перев'язав дорогу!» [Воропай, 260], «Не сам я йду, чорним волом їду, сухою гадиною поганяю, правою ногою на поріг ступаю, своїм ворогам язик одвертаю: щоб вони губами не плямкали $i$ зубами не клачали надо мною, рабою Божою Марією» [УЗ, 190], «Я тебе, дубе, з'їм з корінням, з насінням» [УЧ, 87]. У формі майбутнього часу вживаютья присудки в текстах-висловленнях погрози, яка може супроводжуватися повідомленням умов, за яких вона здійснюватиметься: «Так вас усіх буду драти, як будете на просо літати!» [ЛіС 1992 №1, 54], «Як не будеш родити, то буду тобою паску святити» [Дмитренко, 29].

У ряді випадків магічний смисл дії стверджується через заперечення тієї, яка реально виконується: те, що насправді мовець робить із реальним предметом (речовиною), у замовлянні постає як дія з бажаним предметом, відтак магічна. Таким чином, з одного боку, підкреслюється символічність виконуваної дії, з іншого, - пї рівнозначність дії реальній: «Не хліб ся купає в воді, але $я$ - в здоров $\dddot{\imath} i$ силі!» [Воропай, 147], «Я не беру воду, але мід $i$ вино!..» [Воропай, 147], «Не дірки затикаю, а роти моӥм ворогам, щоб ӥх напасті не зловили мене через увесь рік» [Воропай, 65], «Я не землю то беpy, але беру собі з бджолами рій і порій до своєї пасіки...» [Воропай, 254].

Як бачимо з наведених прикладів, значна кількість однофразових текстів замовлянь-розповідей - висловлення, співвідносні зі складнопідрядними реченнями 3 підрядними мети. Підрядні частини не тільки інформують про мету дій, а й виконують магічну функцію висловлення бажання, тим самим підкреслюючи й посилюючи магічний смисл виконуваної дії. 
Проміжною ланкою між текстами, у яких ідеться про дії мовця, та текстами-розповідями про дії магічних істот, $\epsilon$ тексти із заміщеним суб'єктом дії типу «Не я б'ю - верба б'є, за тиждень Великдень, недалечко червоне яєчко» [Воропай, 357], «Шутка б'є - не я б'ю, віднині за тиждень буде в нас Великдень!» [Воропай, 357]. Виконання певної дії в певний магічно відзначений час приписується магічній істоті (у наведених прикладах - магічному предмету), що й робить цю дію магічною.

Магічні істоти - суб'єкти дій замовлянь-розповідей і самі ці дії визначаються практичним призначенням того чи іншого замовляння та світоглядними уявленнями давніх мовців: «Святий Ягорій Побідоносещь іхав на Осіянській горі, на червоному коні звір-вовків збирати, що не йшли моє стадо поїдати» [Воропай, 70]. Святий Георгій Побідоносець у дискурсивному просторі замовлянь постає замісником купальського Ярила [4, 295], тому йому й підвладні хижі звірі і саме до нього звертаються в замовлянні, призначеному для охорони худоби від хижаків. Магічна сила святого підкреслюється тим, що перебував він «на Осіянській горі», а гора осмислювалася як вершина - центр магічного світу, атрибут «Осіянська» підтверджує це; по-друге, Ягорій їхав «на червоному коні», а «поза вершника і кінь як атрибут для язичницької архаїки рівнозначні вказівці на високе (або найвище) місце персонажа, його причетність до верховних, божественних начал» $[4,297]$, червоний же - це колір влади, «царський» колір $[4,267]$.

Замовляння-розповіді про дії магічних істот мають, як правило, кілька предикатів, серед яких актуалізується найчастіше останній - саме він називає дію, що сприяє досягненню бажаного результату: «Ішов Iсус Христос через три-дев'ять небес, на святу землю ступає, уроки викликає од раба Божого (ім'я)» [BM, 68], «Сидить дід на лозє, дере крупи на нозє, не вміє ні читати, ні писати. Тілько огник запорськати» [CМ, 50], «На синьому морі, на камені ворон сидить, лапами розгрібає, хвостом розмітає, од хрещеного раба Божого Івана всякий пристріт одганяє» [УЗ, 111], «Бігли три дівчини, вирвали три очеретини та заткнули три жерели рабу Божсму Івану...» [УЗ, 63], “Святий Адам брав, Ісус Христос насіння давав, а Господь сіяв, а Мати Божа поливала, та всім православним на поміч давала» [У3, 175]. Суб'єкти магічних дій варіюються в певних межах. Так, припиняє кровотечу, «затикає джерело» і баран [Українці, 282]. У центрі концентричного світу замовлянь («На морі на окіяні... на... дванадияти дубах») перебувають і хвостами уроки (пристріт, перелоги) розмітають «дванадиять соколів» [У3, 99]. Лікарські рослини доглядають й інші християнські персонажі: «Святий Оврам на цее зілля орав, Матер Божа ходила, своїми сльозами росила, і Бога прохала, і нам помагала» [УЧ, 27], «Мати Божа ходила, зілля родила, відром поливала, - нам на поміч давала!» [Воропай-2, 128]. Імена християнських святих у подібних текстах - елемент досить пізній. В основі цих замовлянь - давні уявлення людей про одухотвореність природи. Не відокремлюючи себе від зовнішнього світу природи, 
людина «вбачає усюди життя, будь-яке явище постає перед нею як дія, що передбачає певну діючу істоту... людина... повсюди в природі бачить ті ж події, з яких складається iї власне життя» $[3,13]$. Як людина доглядає культурні рослини, так магічні істоти - лікарські. I саме від цих магічно сильних і могутніх діячів зілля отримує свою цілющу й магічну силу. Яскраво це виявляється в тексті з мотивом заміщення діяча: «Травка-травиия, красна дівиия, не я тебе садила, не я й поливала: Господь тебе садив, Господь і поливав, - всякому християнину на поміч давав!» [Воропай, 129].

Крім того, бажаний стан, зокрема, позбавлення від хвороби, може констатуватися як факт (дієслово-присудок у формі минулого часу): «Бешиха бешишище колюча, шпигуна, пекуча, свербляча, нудюча, вітряна, водяна, кров'яна, пожарна, пристрітна, подумана, погадана, помислена, розійшлась $і$ сему слову амінь!» [УЗ, 113]. До групи кількафразових замовлянь належать, на наш погляд, тексти, у яких подібному зображенню бажаного як факту передує опис дій магічних істот: «Ішов святий Єгор із Осіянських гор і ніс гадючі імена, і приложив ік нарожденному, молитвенному Івану, і опуху нема» [У3, 155], «Ішов Христос, Матір Божа, Пречистая, i кров перестала» [ВМ, 68], «Ішла баба по річці, вела бика на нитці, потім нитку розірвала, в раба Божого (ім'я) кров текти перестала» [ВM, 67].

Як правило, магічні істоти - суб'єкти дій замовлянь перебувають у дорозі: вони йдуть, щоб щось зробити, чи йдуть і роблять. Відповідно текст ускладнений або однорідними обставинами мети, вираженими інфінітивом, або однорідними присудками. У мотиві мандрів, за свідченням М. Новикової, переплітаються кілька міфознаків: дороги як випробування, чужинного походження як чудесності (чужинець завжди трохи чаклун), невпізнання (мандрівник - одна із іпостасей «невпізнаного бога» ще в індоєвропейській міфології) [4, 298]: «Іила свята Пречиста з Києва і несла із риз платочок рану затуляти і кров замовляти» [Українці, 282], «Ішов святий Петро і Павел з Пресвятою Богородицею високих гір ворочати, вниз води спускати, з раба Божого Івана уроків, примовок знімати, чоловічих і жіночих, парубочих і дівочих, дитячих, вітряних, водяних, подуманих і примовлених, з очей карих, очей синіх, з очей красних, з очей білих...» [УЗ, 94], «Ішов чернещь попід горою та ніс кувшин меду з собою та спіткнувсь на пеньок та висипав нам у квашу медок» [Українці, 202].

Як свідчать приклади, значна кількість однофразових замовляньрозповідей містить підрядні мети, які вносять у текст відтінок модального значення бажання: «Прийшов козак під вікно, щоб наша кваша була, як вино» [Українці, 202], «Був собі молодожін та держав дев'ять жін, од дев'яти до восьми, а од восьми до сьоми, од сьоми до шести, од шести до n'яти, од п'яти до чотири, од чотири до три, од три до дві, од дві до однії; щзоб не було в полової корови червяка ни одного» [Українці, 282]. Предикативна частина на позначення мети дії, бажаного стану може приєднуватися до розповідної за допомогою частки «нехай (хай)»: «Золот Симон 
оре, а Спаситель сіє, нехай приймається, а я зілля нарву, нехай помагається!» [Воропай-2, 134], «Цей мертвий замира, нехай рабі Божій Матії гризь отбира» [УЧ, 86]. Частки «нехай» у наведених прикладах виступають і як модальні (бажальні), і як формотворчі (утворюють аналітичну форму наказового способу дієслова 3 ос. одн.), тому в текстах поєднані розповідна, бажальна й спонукальна модальності. Розповідна частина констатує наявність магічної сили, спонукально-бажальна спрямовує їі дію в потрібне русло.

Замовляння-обереги є повідомленням про чудесне просторове огородження: мовець констатує наявність магічних захисних сил з усіх сторін, а також інформує про їх допомогу: «Хрест на хаті, анголи в хаті, Icyc Христос на вікні при нашому сні» [Онищенко], «Іду я з хати, за мною Сус Христос і Божая Мати, Миколай на порозі - помага мені в дорозі» [УЗ, 196], «Виходжу з двора, як ясна зоря, місящем підпережуся $і$ нічого не боюся» [CM, 43].

Окремим семантико-синтаксичним різновидом замовлянь-розповідей $\epsilon$ тексти, в яких виконання певної бажаної дії в майбутньому ставиться в залежність від певних умов: «Як оцей павук заснує, - кого схочу, той до мене приснує» [УЧ, 13], «Як павук на віниях буде, то що задумаю - те й буде!» [УЧ, 7]. Обидва тексти $є, з$ одного боку, ворожіннями, оскільки напевне не відомо, чи буде виконана умова, і саме ії виконання буде знаком реалізації чи нездійснення бажання. 3 іншого боку, ці тексти виголошуються не з метою дізнатися про майбутнє, а з метою його сконструювати в бажаному напрямку, і тому належать до замовлянь.

До замовлянь-розповідей відносимо і конструкції «нездійсненної умови», які М. Новикова розглядає серед способів «зменшення буттєвості» лихого й шкідливого [4, с. 286, 289-290]. Словесно виконання небажаної, шкідливої для мовця дії стає можливим лише після виконання певної реально нездійсненної умови: «Тоді будеш ходити, як иеей мак перелічиш!» [ЛіС 1992 №7-8, 56], «Хто сей мак збиратиме, той мою скотину з '̈датиме» [Українці, 288], «Хто очей мак ізбере, то той у корови $і$ молоко одбере» [Українці, 288]. Ці тексти супроводжували обряд осипання хліву чи подвір'я свяченим маком, що мало на меті убезпечити худобу від відьом.

Отже, основна функція замовлянь-розповідей - констатація бажаного як факту, чим пояснюється значна перевага часової віднесеності описуваних дій до минулого й теперішнього. Серед замовлянь-розповідей за семантико-синтаксичними й функціональними ознаками виокремлюються: повідомлення про дії мовця, опис дій магічних істот, повідомлення про майбутні дії, залежні від певних умов. Підрядні речення мети вносять у текствисловлення відтінок бажального значення. 


\section{Список умовних позначень}

ВМ - Вербальна магія українців / Вст. сл. Л. Дунаєвська; авт. передм. О. Павлов; упоряд. та прим. Т. Полковенко, В. Фісун. - К.: Бібліотека українця, 1998. - 98 с.

Воропай - Воропай О. Звичаї нашого народу: Етнографічний нарис: У 2-х т. Т. 1. - К.: МВП «Оберіг», 1991. - 450 с.

Воропай-2 - Воропай О. Звичаї нашого народу: Етнографічний нарис: У 2-х т. Т. 2. - К.: МВП «Оберіг», 1991. - 447 с.

Дмитренко - Дмитренко М. Народні повір'я. - К., 1994. - 67 с.

ЛіС - журнал «Людина і світ»

Онищенко - інформант Онищенко Катерина Демидівна (1917-2003 pp.), с. Мала Олександрівна Великоолександрівського району Херсонської області

СМ - Словесна магія українців / Упоряд., авт. передм. В. Фісун. - К.: Бібліотека українця, 1998. - 102 с.

УЗ - Українські замовляння / Упоряд. М. Н. Москаленко; Авт. передм. М. О. Новикова. - К.: Дніпро, 1993. - 308 с.

Українці - Українці: народні вірування, повір'я, демонологія - К.: Либідь, 1991. $-640 \mathrm{c}$.

УЧ - Українські чари: 2-ге вид., стереотип. / Упоряд. О. М. Таланчук. - К.: Либідь, 1994. - 96 с.

\section{Список використаної літератури}

1. Бахтин М. М. Литературно-критические статьи / Сост. С. Бочаров и В. Кожинов. - М.: Худож. лит., 1986. - 543 с.

2. Зелинский Ф. Ю. О заговорах (история развития заговора и главные его формальные черты) // Сб. Харьковского истор.-филол. общества. - Харьков, 1897. - T. 10. - C. 1-58.

3. Крушевский Н. Заговоры, как вид русской народной поэзии // Варшавские университетские известия. - 1876. - №3. - С. 3-69.

4. Новикова М. О. Коментар // Українські замовляння / Упоряд. М. Н. Москаленко; Авт. передм. М. О. Новикова. - К.: Дніпро, 1993. - С. 199-306.

\section{Summary}

The article is devoted to the semantic and structural peculiarities of one group of Ukrainian one-phrase charm exorcist texts - texts-narrations. These peculiarities are provoked by communicative task and magic function of these texts. Charm exorcist narrations are represented definite psychological peculiarities of speaker. 